\title{
Analysis of Caryl Churchill's Feminism Deconstruction on Top Girls
}

\author{
Dan Yang ${ }^{1}$ \\ ${ }^{1}$ Associate Prof., Foreign Language School, Yancheng Teachers' University, Yancheng, Jiangsu, China \\ Correspondence: Dan Yang, Foreign Language School, Yancheng Teachers' University, Yancheng, Jiangsu, \\ China. E-mail: 409760370@qq.com
}

Received: September 15, 2019 Accepted: November 5, 2019 Online Published: November 14, 2019

doi:10.5539/ells.v9n4p74 URL: https://doi.org/10.5539/ells.v9n4p74

\begin{abstract}
This study, based on identity and selfhood in postmodernism, probed into feminism deconstruction, which would help to interpret the postmodernism narrative trends in contemporary English plays. With the purpose to make sarcasms on "top girls", she deconstructed feminism through four aspects: feminine characters disrespected other feminine characters, feminine characters gave up feminine and motherhood identities, feminine characters' success in different times and spaces embodied their sufferings, and the play without male characters was full of male's impacts everywhere. By means of deconstructing feminism, she made sarcasm on top girls and blamed the power systems in the current society.
\end{abstract}

Keywords: feminine characters, postmodernism, identity, selfhood

\section{Identity and Selfhood in Post-Modernism}

With the coming of post-modernism, the academic circles commonly hold that the traditional structure, a great narrative style, or a summarizing-everything style, has been ended (Bi \& Fu, 2007). A mentality, which held that we were heading on the way towards common goals, like knowledge, equality and justice, had been gone forever (Foucault, 1978). On the contrary, multiple paths, multiple features and differentiation as well as partial understanding of knowledge, which means we can only get a partial understanding of knowledge and all knowledge is partial, have begun to be emphasized. Changes can be seen, not linear ones, but constructions of some webs, connections and re-connections, because they are always being formed and re-formed and never have the time for being stressed.

Therefore, modern mentality stresses direction, order, coherence, stability, brevity, control, quality and universality, while post-modernism stresses deconstruction, variety and incoherence. In modern thoughts, people are coherent individuals, or "selves". Their mentality and acts are independent of others. This mentality is obvious and natural for people who have received education and cultural fostering in western European systems, which can be traced back to specific "self" concepts in Renaissance thoughts, called construction. However, the "construction" concept has problems in post modernism.

In the daily world, the modern thought on "self" has long been substituted. People have various ways of existence and people own various relationships and connections. They have lots of conflicting parts among them in the meantime. When people enter and retreat from all occassions, cultures and all series of thoughts, their mentality and behaviors all change towards others. They are aware that different occassions have different behavior norms, they are constructed by people in different ways on different occassions and they also construct themselves in different styles. They think that they behave better in some circumstances than in others. Individuals in post-modern age are hybrids. They own not only eternal "selves", but also "countless individuals". Their "selves" and their identities are not fixed but in a constantly changing process, just like that they have constantly changing borders and their body parts can also be negotiated.

\section{Identity and Selfhood in Postmodern Plays}

"Selfhood" can be defined as a self with a definite identity, fully-developed humanity and mentality (Anderson, 1996). The achievement of a definite identity or forming of a definite character has been a focus of the literary circle and it has been this case for feminine identities. In the past century, much has been done in this regard but it still has much to be done on the global scale.

A definite identity or self mentality in post-modernism plays has several definite features: mental space in 
theatrical performance; having the capacity not to choose a solution but to give the audience self-consideration or emphasis; it's vital for playwrights not to seek a solution as it's risky to destroy the embryo of social scenario with future changes; playwrights use space between extremes like male and female, power and powerlessness, caring and being patriarchal actors usually don't go to a definite category. Caryl Churchill (1938-), the English playwright, has been regarded as a main post-modernism playwright in the modern world.

Caryl Churchill promoted self-renovation at the same time, taking characters and the audience to a holy space of empathy and interrelationship. Her first stage play "top girls" (1982) widened the topic of "self concept", increasing the elements of two extremes between paternalism and patriarchism, exposing the distinction between disorganization and self without a thought. This play was set in the early period of Thatcher age, considered as a trailer of socialism in free market economy, reducing the national intervention and government service loss. In the meantime, this play expressed Churchill's pointing to feminine identity and self, achieving the deconstruction of feminism in the contemporary age.

\section{Deconstruction of Feminism: Interpretation of Feminine Identity and Selfhood}

\section{Feminism Deconstruction Device No. 1: Feminine Characters Disrespected Feminine Identity}

In Top Girls, many critics mentioned Marlene's cruel attitudes towards the women she interviewed. Amelia Howe Kritzer (2008) pointed that Marlene despised and even threatened the women seeking employment, so as to defend her own power. When a candidate Jenny told her that she intended to make more money in order to save money for getting married, Marlene despised her. Marlene seemingly cared for Jeanine and reminded her not to mention her marriage plan to her future boss as the future boss possibly wouldn't employ a girl intending to get married. Although it was suspected that she was also one of the employers in the same category, the big social context couldn't be overestimated at all. Marlene, the "top girl", seemed to be a female -surpassing male. This play was produced in 1982, when the "iron lady" Madam Thatcher was appointed the prime minister of England and was taken as Marlene's model. Seeking the value of an "iron lady", Marlene was struggling in gaps of patriarchy systems, by occupying male's field and substituted the male colleague Howard. She took advantage of male's strength and attacks, disrespected the woman, who was seeking employment, in the interview. Her "success" couldn't defend her change of feminine social status, but reverse the traditional social feminism, which was a de-feminism mark device she used to deconstruct feminism in postmodernism.

\section{Feminism Deconstruction Device No. 2: Feminine Characters Gave up the Motherhood Identity}

In the last scene, Churchill's criticism towards Top Girls was not Marlene's failure as a woman (as she gave up her role as a mother) but the society forcing women to take such decisions. Marlene avoided having more children all the time, although she said it wasn't a problem. In order to suit the role of a particular social role, she gave up the role as a mother to seek power and success. Therefore, the audience might admire Marlene's "successful" identity, they should reflect on her sacrifices and her options then, including her deliberate distances with mother, younger sister, daughter (niece), all which intensified her certain attitude towards women. Marlene erased her gender feature and advantage when she entered the male's world, and erased her responsibilities in marriage, family and birth, changing herself into a male psychologically. At the end of scene two, Marlene looked at Angie who was asleep on the desk, saying that she wouldn't deal with it. Her words expressed the sadness from incongruity between physiological state and psychological state. Obviously, Marlene achieved "success" by giving up her baby, which was a "success" in the framework of the male's traditional patriarchal system. The "top girl" title wasn't built on the basis of feminine liberation or feminism maintenance, but on their de-feminism life attitude and on their voluntary discarding their motherhood identity and selfhood. They achieved "success" by male's stance, which was essentially admission and yielding to the patriarchy society. Like Marlene, Lady Thatcher gave up female's identity, acquiring her social position and her title as the "iron lady". If Queen Thatcher could be a historical figure to represent successful female, what "Top Girls" wanted to hint was that equality was only deceit and women had to be more like males so that they could go upward in the system. It wasn't real equality and it was also Caryl Churchill's device to deconstruct feminism.

Feminism Deconstruction Device No. 3: Female Characters in Mixed Time and Spaces Embodied Female Characters' Sufferings

Churchill interpreted the concept of "huge advancement" for so many centuries. The "successful women" in "Top Girls" represented all cultures, classes and ages, almost all of which contained women's great stories. In "Top Girls", the writer intended to display females' "success", but the audience didn't see the real encouraging successful stories when the connotation of success was disclosed, but the incongruous sufferings of females. The actress Marlene was a "top girl", but the audience eventually knew that Marlene paid a lot for the sake of her identity. Helene Keyssar commented that we should take Marlene seriously, as she was also a woman and she 
shouldn't be a simple admirable character as a model of success (1985). For one more example, Lady Nijo, the Japanese emperor's courtesan and later a Buddhist nun who traveled on foot through Japan was officially the emperor's courtesan, another "top girl". However, when Caryl Churchill disclosed the veil of success, what the audience saw was that she acted as the emperor's socializing tool, having sex with other men and giving birth for other men at the emperor's command. Experiencing abortions and losing children, she turned out to be a Buddhist nun who traveled on foot through Japan. Her "success" was female's humiliation without happiness or joy. She underwent sufferings all her lifetime. Whether her experience was success could resort to the audience's judgment.

Feminism Deconstruction Device No. 4: The Play without Males was Abundant in Male's Impacts

As Churchill's only play without a male role, Top Girls was abundant in male influence everywhere, because most women's choices and attitudes were clearly defined, all related to males. For example, the female's stories focused on their options determined by males, especially by fathers and husbands. Furthermore, two roles on the dinner table were obviously created for males, which hinted that females lacked recreational self-control. These figures were recreated in women's works and were given new life and told their stories. For example, women's stories at the beginning focused on the choices, males had made for them, especially father and husband. And the two roles at the dinner table were obviously roles created by males, which suggested that women lacked the recreation control towards themselves. These characters were recreated, given new life and telling their stories from a new feminine perspective. In the play, the absent males exerted huge influence toward women, such as Marlene and Joyce's father, Angie's unnamed and unmentioned birth father, adopted father, Joyce's ex-husband, Marlene's colleague Howard, sometimes who were exerting extraordinary influence. Women didn't have the same freedom and rights as men most of the time in the play. When women took leading positions, they were criticized when they occassionally made minor mistakes. The females' words in the celebration banquet absent of males, were chaotic like dream words, and their whole life and mentality were included in the social system featured as patriarchism. If women wanted to acquire success, they had to depend on rules in the patriarchy system. These plots constituted sharp contrast with "success", featuring huge gap between females' success and female's whole liberation, intensifying the sarcastic meaning towards "top girls".

\section{Conclusion}

Churchill had full aspiration towards the social system reforms of the capitalist system. She wished that career women and housewives could be given more tolerance and understanding, and she pushed her characters in her plays to dilemma again and again, reminding the audience to focus it and to seek way out (Zhang, 2017). Caryl Churchill deconstructed feminism in the play, deconstructed feminine figures' identity and selfhood in the patriarchy society and blamed the contemporary society's power system.

\section{References}

Amelia, H. K. (2008). Political Theatre in Post-Thatcher Britain: New Writing, 1995-2005 (p. 137). Springer.

Anderson, W. T. (Ed.) (1996). the Fontana Postmodernism Reader (p. 325). London: Fontana Press.

Bi, F, S., \& Fu, J. (2007). English Contemporary Theatre and Post-modernism (vol. 9, pp. 53-56). Foreign Language and Foreign Language Teaching.

Caryl, C. (1982). Top Girls (p. 17). Samuel French, Inc.

Foucault, M. (1978). The History of Sexuality: An Introduction (Robert Hurley Trans., p. 137). Harmondsworth: Penguin.

Helene, K. (1985). Feminist Theatre: Introduction to Plays of Contemporary British and American Women (p. 89). Scholarly and Reference Division, St. Martin's Press, Inc. https://doi.org/10.1007/978-1-349-17681-6

Zhang, W. J., \& Qian, J. (2017). Aspirations for Social Reforms (vol. 11, p. 47). Sichuan Theatre.

\section{Notes}

Note 1. Affiliated Project 1: "Family Ethic Narration Research in Contemporary English Plays" administered by Education Ministry of China (14BWW051).

Note 2. Affiliated Project 2: Univeristy Brand Construction Project in Jiangsu, Phase One (Project Number: PPZY2015A012).

Note 3. Affiliated Project 3: Yancheng Teachers University Teaching Reform Project (Project Number: YCTCJY026). 
Note 4. Affiliated Project 4: Jiangsu Provice Teaching Reform Project (Project Number: YT201909).

\section{Copyrights}

Copyright for this article is retained by the author, with first publication rights granted to the journal.

This is an open-access article distributed under the terms and conditions of the Creative Commons Attribution license (http://creativecommons.org/licenses/by/4.0/). 